\title{
MARKETING IN THE PRE-DEVELOPMENT PROCESS OF AGRICULTURAL MACHINES: A REFERENCE MODEL
}

\section{ALEXANDRE S. DE OLIVEIRA ${ }^{1}$, ARNO U. DALLMEYER ${ }^{2}$, LEONARDO N. ROMANO ${ }^{3}$}

\begin{abstract}
The theme of the research is the development of the domain of marketing knowledge in the design of agricultural machinery. It is developed throughout the design of agricultural machinery in order to identify the corporate and customers needs and to develop strategies to satisfy these needs. The central problem of the research questions which marketing tools to apply on pre-development process of farm machinery, in order to increase the market value of the products and of the company and, consequently, generate competitive advantage to the manufacturers of agricultural machinery. As methodology, it was developed bibliographical research and multicase study of the development process of agricultural machinery developed by small, medium and large companies and the academy. As a result, a marketing reference model was elaborated for the pre-development stage of agricultural machinery, which outlines the activities, tasks, mechanisms and controls that can be used in strategic planning and in products planning of agricultural machinery manufacturers, contributing to explain the explicit knowledge in the marketing field.
\end{abstract}

KEYWORDS: product design, agricultural mechanization, marketing techniques.

\section{MARKETING NO PRÉ-DESENVOLVIMENTO DE MÁQUINAS AGRÍCOLAS: UM MODELO DE REFERÊNCIA}

RESUMO: O tema de pesquisa é o desenvolvimento do domínio de conhecimento de marketing no projeto de máquinas agrícolas. Este é desenvolvido ao longo do projeto de máquinas agrícolas a fim de identificar as necessidades dos clientes e da corporação e criar estratégias para que sejam satisfeitas. O problema central de pesquisa questiona quais mecanismos de marketing utilizar no processo de pré-desenvolvimento de máquinas agrícolas, para aumentar o valor de mercado dos produtos e da empresa e, conseqüentemente, gerar um diferencial competitivo às fabricantes de máquinas agrícolas. Como metodologia desenvolveu-se pesquisas bibliográficas e estudo de multicasos do processo de desenvolvimento de máquinas agrícolas desenvolvido pelas pequenas, médias e grandes empresas e pela academia. Como resultado elaborou-se um modelo referencial de marketing para a etapa de pré-desenvolvimento de máquinas agrícolas, que aponta as atividades, tarefas, mecanismos e controles que podem ser utilizados no planejamento estratégico e no planejamento de produtos das empresas fabricantes de máquinas agrícolas, contribuindo para a explicitação do conhecimento do domínio de marketing.

PALAVRAS-CHAVE: projeto de produto, mecanização agrícola, técnicas mercadológicas.

\footnotetext{
${ }^{1}$ Prof. Dr., Universidade Federal do Pampa - UNIPAMPA.

${ }^{2}$ Dr., Universidade Federal de Santa Maria - UFSM.

${ }^{3}$ Prof. Dr., Universidade Federal de Santa Maria - UFSM.

Recebido pelo Conselho Editorial em: 10-6-2010

Aprovado pelo Conselho Editorial em: 10-2-2012
} 


\section{INTRODUCTION}

It is undeniable the importance of the agricultural machinery sector in the Brazilian economy, for the amount of jobs, tax revenue and share in national product. However, this sector lacks management tools to design products that fit the national reality, because most companies in the sector can only import technologies and management techniques from large foreign companies that have financial, technical and human resources to build the necessary means to obtain the purposes, in contrast to our reality.

Brazilian companies of agricultural machinery, to be competitive, need as management and philosophy the principle of innovation, dictating the trend of the moment in their industry. They need to anticipate market changes (BACK et al., 2008), using capabilities such as cutting-edge technology, competent and service updated personnel, knowledge of field and qualified technical advice, especially with respect to Product Development, such as conducting market research (TEIXEIRA et al., 2009), and consumer trends, to create competitive advantages that really last.

To create lasting advantages, companies need to accurately predict what the future trends are and, thus, use their resources, which in most companies is quite limited.

With respect to most companies of agricultural machinery and implements, it is formulated products without a definition of formalized process and questioning their logic.

In field service, a salesman visits a customer. The product does not meet specifications, correctly, and they work together some modifications. The salesman returns the product to the manufacturer to make the changes. After two or three other feedbacks, they finally get to the implementation of corrections. A new product emerges, which eventually opens a new market. The company, thus, developed its marketing of integrated development.

With globalization and increased competitiveness, a new change occurs. Domestic companies can no longer rely on strategies as simple as the aforementioned, which have long cycle duration; or on the strategy of benchmarking, which is limited to import new technologies developed abroad and reproduce them on the domestic market. They now need flexibility and innovation (ROZENFELD et al., 2006), especially regarding to the development of new products with the use of projective techniques which incorporate strategic and marketing planning. Through this perspective, the delimitation of the problem was: Which are the marketing mechanisms used in the Process for PreDevelopment of Agricultural Machinery, to increase the market value (for the customer and therefore the financial value) of products and of the company and, thus, to generate a competitive advantage to manufacturers of agricultural machinery?

There is the need to use a methodology for the pre-development process of agricultural machinery design suited to the Brazilian needs, which presents the use of marketing mechanisms, essential for the so expected success of the products.

The major contribution of this study for the design of agricultural machinery is the inclusion of a vision of the project pre-development, which involves the corporate strategic planning and product planning, even before the birth of the agricultural machinery design, with an appropriate language and process which attend to organizational objectives and to the market, considering the exposed limitations for its implementation, and the construction of a reference model for the predevelopment of agricultural machinery under a marketing vision.

\section{MATERIAL AND METHODS}

This is a research of an exploratory descriptive delimitation, developed through the methods of bibliographic research, case studies and directive interviews, and the processing of data is qualitative. The research focuses on bibliographic research and interviews collected in books, magazines, newspapers and interviews of companies and professionals of the field. As a research 
strategy, the bibliographic research and multicase study were applied in order to obtain a content analysis in data handling.

It was held, in form of bibliographic research, the study of marketing knowledge applied during the development process of agricultural machines and of planning mechanisms for marketing proposed by ROMANO (2003). Using the strategy of multicase study, it was conducted a survey of the development process of agricultural machinery and the profile of agricultural machinery companies, observing the case of four dealers of agricultural machinery, fourteen small and medium-sized manufacturers, and two large companies of the sector. The survey allowed to identify the business process, as well as to identify the marketing process in order to obtain subsidies for the development of a marketing model in the pre-development process of agricultural machinery, which would provide the necessary range to become a consistent, deep, and yet clear, study.

For the collection of data, it was performed a literature review of the development process of agricultural machinery, especially the one developed by ROMANO (2003).

In field, two questionnaires were developed and implemented in three moments. First, a questionnaire was given to six farm machinery dealers in Santa Maria, state of Rio Grande do Sul, Brazil. The same questionnaire was applied to small and medium-sized manufacturers of agricultural machinery. And a second questionnaire was applied to the major industries of agricultural machinery.

All the researches are summarily tabulated in Table 1, which illustrates the strategy used for each one. The surveys were conducted in different periods: 2005 , the field research $\mathrm{n}^{\mathrm{o}}$ 1; 2008 and 2007 the other researches.

TABLE 1. Collection of data of the accomplished researches.

\begin{tabular}{l|l|c|c|c|c|c}
\hline & \multicolumn{1}{c}{$\begin{array}{c}\text { Field } \\
\text { Research 1 }\end{array}$} & \multicolumn{1}{c}{$\begin{array}{c}\text { Field } \\
\text { Research 2 }\end{array}$} & \multicolumn{1}{c}{$\begin{array}{c}\text { Field } \\
\text { Research 3 }\end{array}$} & \multicolumn{1}{c}{$\begin{array}{c}\text { Field } \\
\text { Research 4 }\end{array}$} & \multicolumn{1}{c}{$\begin{array}{c}\text { Field } \\
\text { Research 5 }\end{array}$} & $\begin{array}{c}\text { Field } \\
\text { Research 6 }\end{array}$ \\
\hline Public & Dealers & $\begin{array}{c}\text { Small and } \\
\text { médium-sized } \\
\text { manufacturers }\end{array}$ & $\begin{array}{c}\text { Large } \\
\text { company 1 }\end{array}$ & $\begin{array}{c}\text { Large } \\
\text { company 2 }\end{array}$ & $\begin{array}{c}\text { Large } \\
\text { company 3 }\end{array}$ & $\begin{array}{c}\text { Large } \\
\text { company 4 }\end{array}$ \\
\hline $\begin{array}{l}\text { Interviewee } \\
\text { Collection }\end{array}$ & Salespeople & $\begin{array}{c}\text { Project } \\
\text { managers }\end{array}$ & $\begin{array}{c}\text { Marketing } \\
\text { director }\end{array}$ & $\begin{array}{c}\text { Marketing } \\
\text { supervisor }\end{array}$ & $\begin{array}{c}\text { Marketing } \\
\text { manager }\end{array}$ & $\begin{array}{c}\text { Project } \\
\text { manager }\end{array}$ \\
\hline 1 & Questionnaire & $\begin{array}{c}\text { Interviews } \\
\text { based on } \\
\text { Questionnaire } \\
\text { but were not } \\
\text { structured and } \\
\text { recorded }\end{array}$ & $\begin{array}{c}\text { Interview } \\
\text { using } \\
\text { Questionnaire } \\
\text { 2, recorded }\end{array}$ & $\begin{array}{c}\text { Interview was } \\
\text { not structured } \\
\text { (recording not } \\
\text { allowed) }\end{array}$ & $\begin{array}{c}\text { Meeting and } \\
\text { documents } \\
\text { analysis }\end{array}$ & $\begin{array}{c}\text { Interview } \\
\text { was not } \\
\text { structured, } \\
\text { recorded and } \\
\text { documents } \\
\text { analysis }\end{array}$ \\
\hline
\end{tabular}

Data analysis was performed on spreadsheets and flowchart programs. Data from different researches were tabulated and analyzed in different ways. For the first two field researches, involving agricultural machinery dealers and small and medium-sized manufacturers of the sector, the data were compared to verify consistency among the responses of the two sectors.

During the construction of the model, the presentation of the activities of marketing knowledge domain is done through the stages of pre-development, Figure 1 - Strategic Planning and Product Planning.

In the information analysis of the remaining phases inherent to the process of development of agricultural machinery (AM), we used the structure of the reference model for the DPAM (Development Process of Agricultural Machinery), ROMANO (2003), organized as: design planning, informational design, conceptual design, preliminary design, detailed design, preparation for production, launch and validation. 


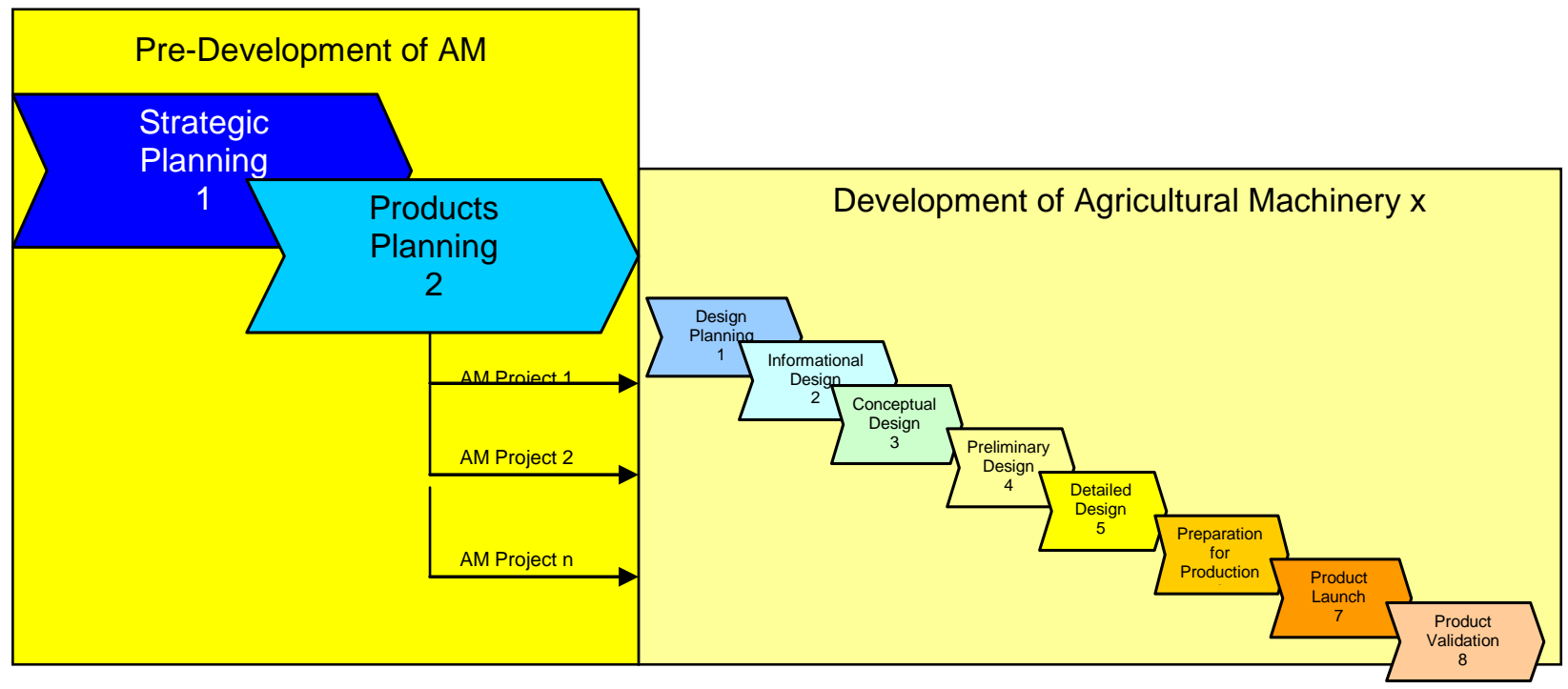

FIGURE 1. Phases of the proposed pré-development and phases of the development of agricultural machines (ROMANO, 2003).

These phases are divided into activities and tasks, and has a systemic character, with inputs and outputs, Figure 2, as the model used by IDEF0 (Integration Definition for Function Modeling), created by the U.S. Air Force, as an extension of the SADT model (Structured Analysis and Design Tecnique), (VERNADAT, 1996).

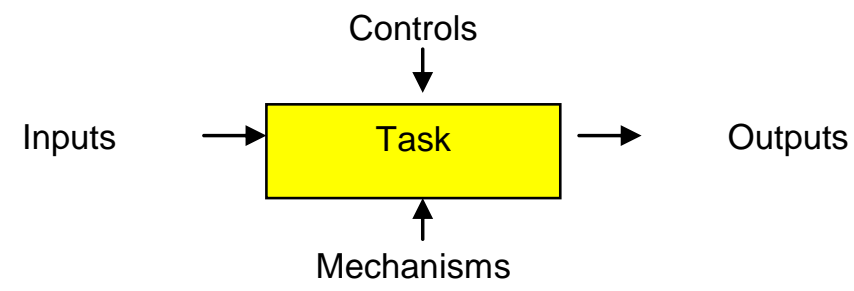

FIGURE 2. Presentation form of the reference model (ROMANO, 2003).

\section{RESULTS AND DISCUSSION}

The following is the marketing reference model proposed for the pre-development of agricultural machinery.

It was presented the stages of pre-development and development process with the various marketing activities throughout the project. This model was evaluated with the main companies in the sector as detailed below. It is divided into phases of strategic planning and product planning (Figure 3).

Strategic planning occurs at the corporate level of organization and it has influence on all company activities, in addition to machine design, and usually occurs every year. Its output is the strategic plan, which in relation to marketing provides corporate guidelines for carrying out the next phase.

The product planning, from the strategic plan, develops in the tactical level of the company which machines designs that can serve the intended market and, simultaneously, the desired organizational objectives. It involves tactical level marketing that evaluates the micro-markets and creates tactics for the insertion of machinery in it. It generates as output the plan of agricultural machinery, which has a unique process of project development for each machine. 


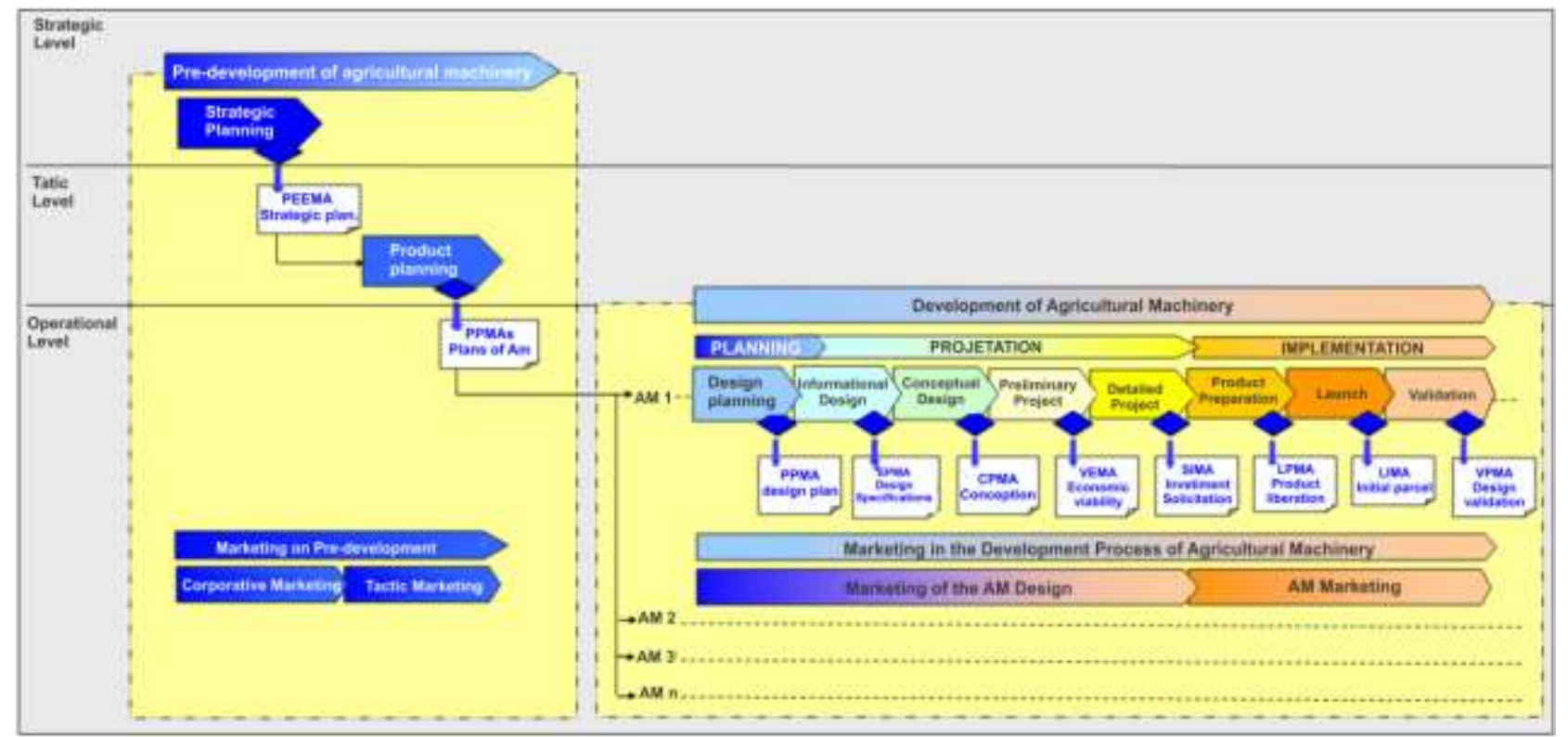

FIGURE 3. General vision of the marketing model in the pre-development and development of agricultural machines.

The process of project development is subdivided into design planning, informational design, conceptual design, preliminary design, detailed design, production preparation, launch and validation. By the end of the projecting, the realization of the marketing project occurs, which involves in marketing activities that will feed the project with information for the development of the specific machine. Since the launch, there is the marketing development of the agricultural machine or the out marketing, aiming to promote the machine on the desired market with a set of techniques that involve sales effort. Also each stage generates an output to the next phase, as in the pre-development, authorizing its continuation and providing necessary support for its implementation.

To easiness of construction, didactic and readability, only the activities and tasks of the stages are here commented. The following are the stages of pre-development process with the different activities and marketing tasks, with the inputs, outputs and controls implementation. As it can be seen in Figure 4, the phase of Strategic Planning is subdivided into 8 activities. The input stage is reflected by the need for competitiveness of the company, which shall analyze the external macro and microenvironment and internal environment of the company.

As schemes, it was used the THOMPSON (1967) $)^{1}$, DELPHI or LORSCH $(1973)^{2}$ and Lawrence (1973) analysis. It was identified the market opportunities and threats, and strengths and faults of the company (FOFAS), with the SWOT tool. Thus, one can define the critical success factors for the company (CSF), the company's guidelines (vision, mission, objectives, goals and strategies), and tactical action plans of the corporation, when it comes to marketing, finance, production, human resources and organizational structure.

Then, the lessons learned were recorded, which are passed on to the stage of product planning. Each of the activities is unfolded into detailed flowcharts of the tasks.

\footnotetext{
${ }^{1}$ Correlation between the continuum of the task environment and the continuum of the operating environment.

${ }^{2}$ Contingentialism analysis. Evaluates environmental requirements for creating an appropriate structure to face such environment.
} 


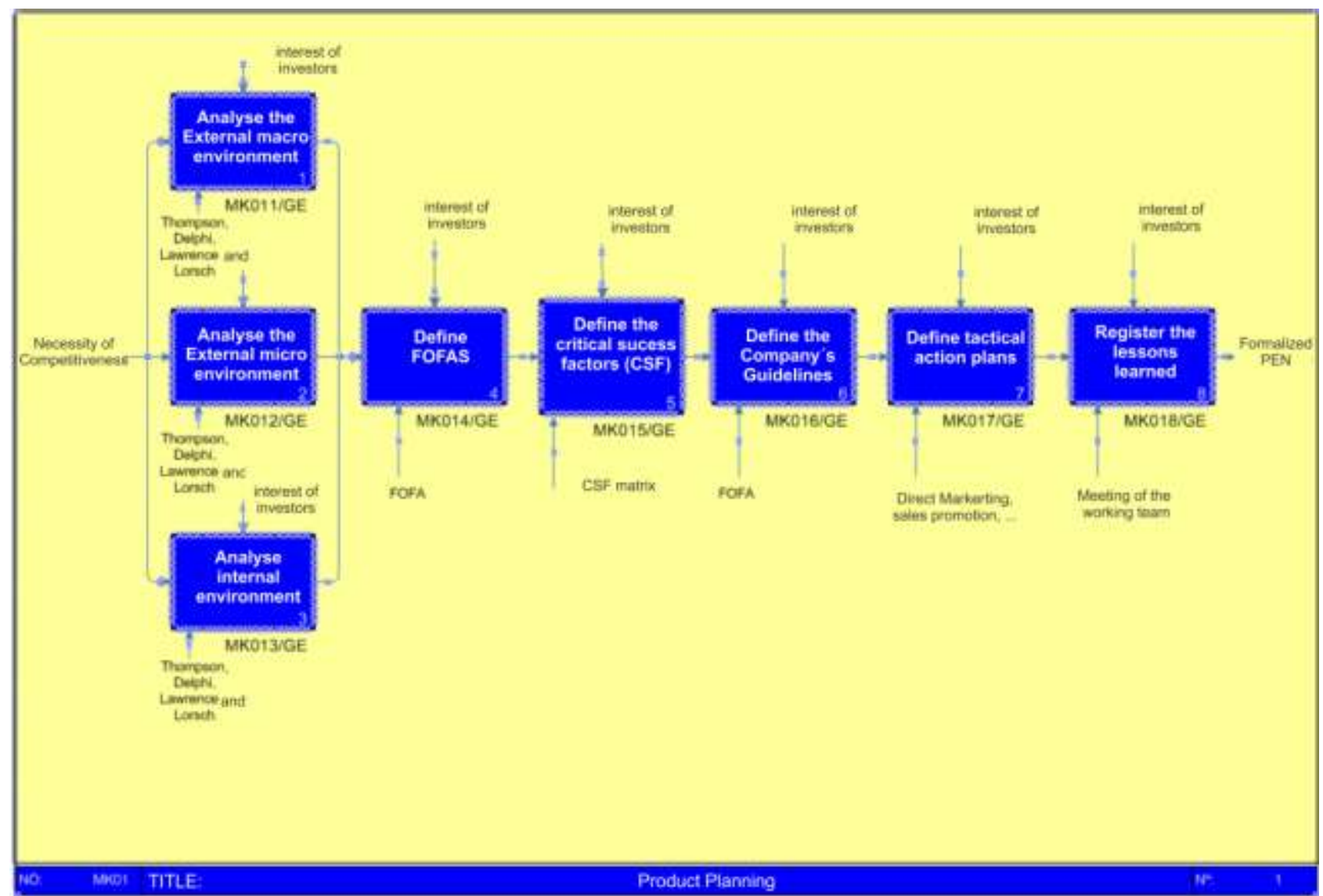

FIGURE 4. Phase of Strategic Planning.

The analysis of the external macro-environment unfolds in the tasks of analyzing culture, examining the society, analyzing the technology, analyzing the economy, analyzing the natural environment, analyzing the policy and legality, and analyzing the demographics. As the main work tool, it is presented the use of matrices such as Lawrence and Lorsch, and Thompson.

The activity of analyzing the external microenvironment, unfolds in the tasks of analyzing customers, competitors, suppliers, distributors, banks, government, unions, and media.

In the activity to assess the internal environment of the company, it is necessary to develop the tasks of analyzing people, finances, organization, production and marketing of the company.

When analyzing the marketing, it is necessary to: review the business segmentation, market positioning, the focus of strategic business unit (SBU), the methodology for evaluating the portfolio; evaluate the product positioning, performance of products, technologies and platforms used; consolidate the list of new product ideas; analyze the designs, methods, tools and documents; and analyze the methods of analysis for product positioning.

The activity of defining the tactical plans of action unfolds in eleven tasks: define the marketing plan, define the organizational plan, set the financial plan, set the HR plan, define the production plan, review technology trends, review the vision and mission, review the skills, review required resources, review goals, and prepare the documentation.

At the Product Planning stage, Figure 5, it begins with the development of strategic marketing planning, the market analysis again using the Thompson, Delphi, or Lawrence and Lorsch matrices, and reassessment of the guidelines. From strategic marketing planning, market segment and guidelines must be submitted for approval at a marketing team meeting with the company's board.

Follow with the assessment of the segment risk (classification of project risks), and guidelines at the tactical marketing level chosen to see their affinities with corporative objectives, and then develop tactical marketing plans, again with a view to the chosen and segmented market. 


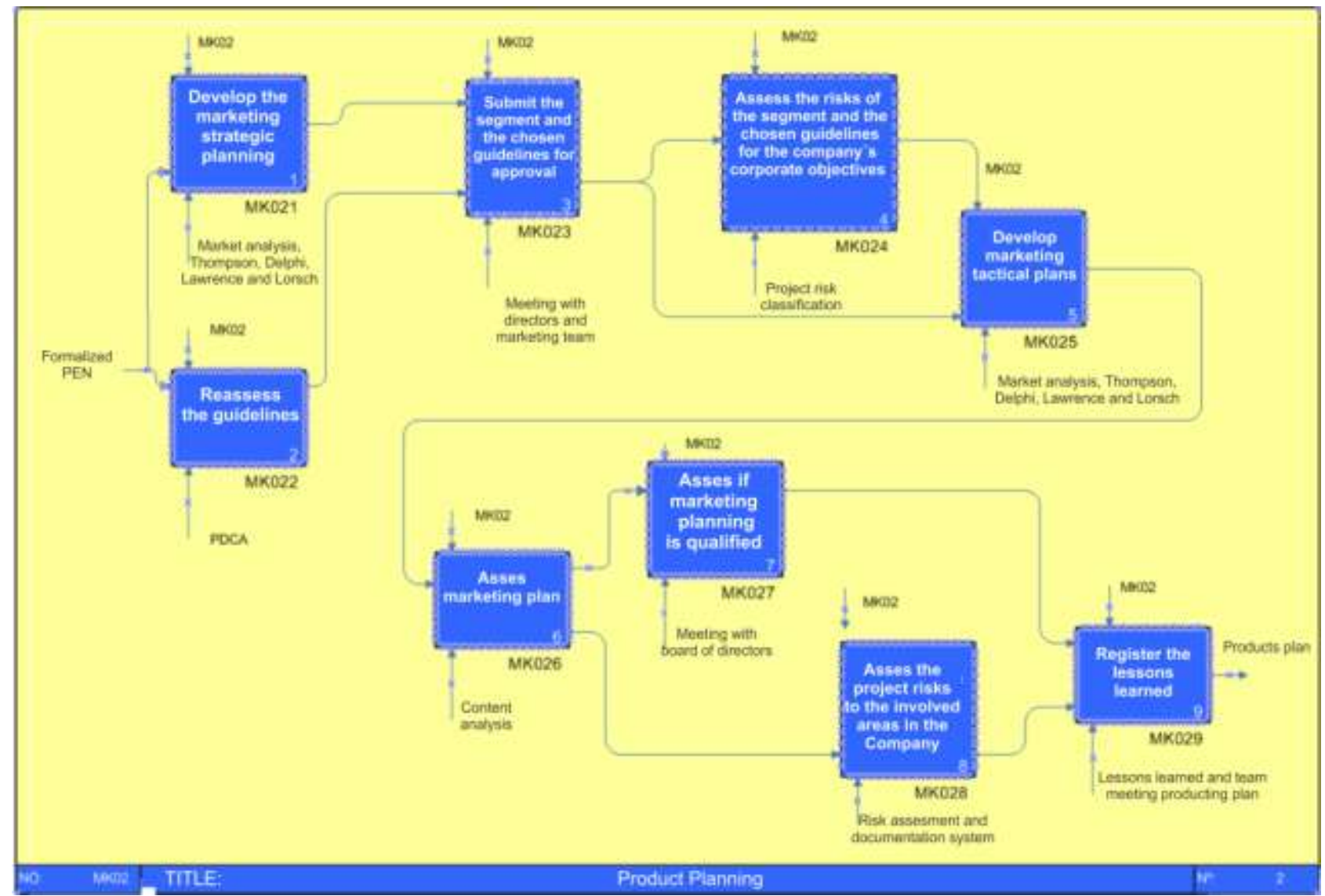

FIGURE 5. Phase of product planning after the validation.

Developed the marketing plan, its contents should be evaluated and analyzed, in respect to their quality (all in a meeting with the board of directors), and the risks associated with other areas of the company, using the generated documentation and evaluation of project risks. Finally, one should record the lessons learned in the marketing team meeting, which will deliver the company's product plan.

It is to reassess the external environment, analyzing the portfolio of existing machines, measure the market size, potential and demand, review the internal environment, and analyze farmer- machine relations.

Yet at this stage, we must understand the relation farmer versus the consumption process, to understand the consumer buying process, segment the market, to position itself in relation to the market by defining the target audience, to choose the segment, to dominate the technology needed, approximate to the farmer, offer machinery and competitive services, identify the products to be discontinued, identify the projects to be abandoned and stopped, and identify new projects to be started in drafts. Then, locate the points of retail and wholesale, use appropriate advertising vehicles, and consolidate the information for marketing planning and review the choice of the segment.

The activity of reassessing the guidelines is subdivided into tasks to reassess the mission and nature of business, communicate the mission and vision, create a culture of communication, review the corporate strategies of price, and reassess the corporate strategies of distribution.

The activity of submitting the chosen segment and the strategies to approval decomposes into the task of issuing the products summary plan with the product strategy. The activity of assessing the risk of the chosen segment and the guidelines for the company's corporate objectives decomposes into assessing risks according to the criteria established for each area and developing responses to project risks. 
The activity of developing tactical marketing plans has the tasks of determining the size of the market, identifying growth opportunities, evaluating the machines available in the market, identifying and analyzing the standards and/or approval criteria for the intended market. Also, set the preliminary purchase price; describe the characteristics of the AM market to define products customers, set annual sales volume, set the launch and advertising costs, according to BARBOSA (2009) and DIAS et al. (2009). And establish the life cycle of AM, consolidate the information of the marketing plan, review the information of the marketing plan, develop the plan of new products, develop the summary plan of sales, develop the advertising plan, and develop the merchandising plan.

The activity of evaluating the marketing planning has tasks of: assessing if the objectives are clear, measurable, challenging and yet achievable; assessing if the growth sectors, stagnant and declining, have been identified; reassessing the strengths and faults of the company; evaluating if the plan takes advantage of the skills and vulnerability of the company; reassessing the target markets - who buys the AM and who makes the decision to purchase; evaluating if the previously existing AMs meet the desires of the target market, and how the trends and demands of farmers will affect them; assessing what are the ways to promote the AM for customers - which information they desire and how to obtain them; evaluating where customers like to buy and their location; evaluating the competition prices and the sensitivity of farmers to price changes; and evaluating the costs and benefits of the plan and the resources needed to put it into practice.

Among the activities described as essential, we can list: to assess if the plan takes advantage of the skills and vulnerability of the company, which can be accomplished with the use of a strategic matrix ${ }^{3}$, considering the strategic business plan of the company. The preliminary assessment of existing AMs to verify if they attend to the wishes of the target market and of how the trends and demands of farmers will affect them can be accomplished with a survey of customer satisfaction. The evaluation of the ways to promote the AM can be accomplished with the observation of market defects, with the use of primary and secondary data.

The analysis of where customers like to buy can be obtained from research in primary and secondary data on the volume of sales per outlet. The sensitivity of the farmer to price changes can be obtained from the analysis of price competition and the calculation of beta regression of price versus sales volume.

The evaluation of cost/benefit of the plan and the necessary resources must be aligned to the strategic business plan and have a ratio lower than the value 1.

The reference model for DPAM of ROMANO (2003) foresaw the activity to assess risks without presenting the unfolding of the tasks performed here, which measure risks of: developing the wrong product and design, developing the wrong customer, developing the wrong market, developing at the wrong moment, selling the wrong way, as to develop wrong and why develop wrong. As mechanisms, we can use heuristic rule ${ }^{4}$.

Altogether the marketing model has in the pre-development, the focus of the study, 17 activities and 106 jobs, according to Table 2.

In the pre-development, the strategic planning phase has 8 activities that break down into 45 tasks. The Product Planning phase has nine activities and 61 tasks.

In addition to the ROMANO model (2003), under the aspect of marketing domain, predevelopment activities are identified (in strategic planning and in product planning).

\footnotetext{
${ }^{3}$ Covers the strategic objectives contemplated by the project and the success factors that it considers for each of the audiences to which they intend their activities.

${ }^{4}$ Instrument that puts into columns and combines the various factors that can generate alternatives.
} 
TABLE 2. Summary of the reference model for the marketing in the Pre-Development and comparison with the activities with participation of the marketing domain (ROMANO, 2003).

\begin{tabular}{lcccc}
\hline & \multicolumn{2}{c}{ Model Proposed } & \multicolumn{2}{c}{ DPAM of ROMANO (2003) } \\
\hline & \multicolumn{2}{c}{ Quantity } & \multicolumn{2}{c}{ Quantity } \\
\hline Strategic Planning & Activities & Tasks & Activities & Tasks \\
Product Planning & 8 & 45 & - & - \\
Design Planning & 9 & 61 & 5 & 15 \\
Informational Design & - & - & 7 & 14 \\
Conceptual Design & - & - & 3 & 5 \\
Preliminary Design & - & - & 6 & 26 \\
Detailed Design & - & - & 11 & 31 \\
Product preparation & - & - & 9 & 23 \\
Launch & - & - & 4 & 13 \\
Validation & - & - & 4 & 6 \\
\hline
\end{tabular}

\section{CONCLUSIONS}

The reference model of marketing in the pre-development process of agricultural machinery has been fully built, considering the information collected from the literature review and field researches.

The marketing knowledge applied during the development process of agricultural machinery is explained, highlighting its importance for the successful marketing of agricultural machinery and of the company (according to the value perspective for the customer and to financial value). The mechanisms of marketing planning in DPAM are identified for the execution of each task presented, ensuring the effectiveness of the tasks. When mapping particular method projects of agricultural machinery industries, it is possible to demonstrate the use of many of the proposed mechanisms. The integration of marketing mechanisms in the reference model for pre-development of AM occurs in a sequential manner and in accordance with the precepts of concurrent engineering, characterizing the effectiveness of the model to cover all activities undertaken by the industry, and offers complementary activities, according to literature and local specifications, such as crop, soil, land structure, diversity and multi-functionality required by the industries in the possible use of agricultural machinery as a form of competitive strategy.

The model offers 106 marketing tasks applicable to pre-development of AM. It is presented mechanisms that can be used to develop each of the tasks, from the examination of all the mechanisms used by the agricultural machinery industry and the ones the current literature presents. And the model integrates the mechanisms evaluated by the four leading and largest manufacturers of agricultural machinery in the country.

It was also possible to conclude that:

- The marketing mechanisms used in the development process of agricultural machinery allow increasing the market value of the products and the company, confirmed by particular models of the dominant industries in the market and the proposed model;

- Marketing activities in the pre-development must necessarily be integrated and applied prior to the reference model of project development of agricultural machinery, increasing its power to meet the demands of farmers and corporate investors.

The major contribution not only to the Academia, but also for businesses, is the inclusion of a vision of pre-development of agricultural machinery design, involving the corporation's strategic planning and product planning, even before the birth of the project of agricultural machinery, with 
an appropriate language and process that allow to meet the organizational objectives and the market, considering the limitations exposed for its implementation.

The proper assessment of the market is essential for the marketing success of agricultural machine. This involves marketing planning, marketing research, sales forecasts, forms of negotiations, the characteristics and needs of agricultural machinery, all to meet the demands of farmers, which are different in each region and crop grown.

A second contribution is the reference model itself in the pre-development process of agricultural machinery in a marketing view, as a way to continue the studies previously done on the design of agricultural machines in a formal and procedural way.

It allows organizing the marketing evaluation processes and of adaptation to the organizational objectives in a logical, sequential way and in accordance with the principles of concurrent engineering, serving as a reference for exercise of this marketing domain knowledge in the pre-development of machines.

As a suggestion for future study, it is recommended:

- The development of other areas in the pre-development that have an influence in the project, such as finance, manufacturing, human resources, organization and structure;

- The study and development of a platform to help enterprises and service companies, with the available database of marketing research related to the sector of agricultural machinery, developed crops, micro-regions, economic, cultural, social and political factors that may affect the design of machines;

- The creation of standard forms for the implementation of marketing activities in the predevelopment of agricultural machinery to facilitate its use and application;

- Integrate the models of pre-development of agricultural machinery to the DPAM reference model in IDEF0 flowcharts in a graphical environment, such as Visio;

- The development of the model in interactive software with the user.

Thus, we conclude this study enabling the advancement of marketing knowledge in the development process of agricultural machinery.

\section{REFERENCES}

BACK, N.; OGLIARI, A.; SILVA, J. C. da. Projeto integrado de produtos: planejamento, concepção e modelagem. Barueri: Ed. Manole, 2008.

BARBOSA, C. Gerenciamento de custos em projeto. São Paulo: FGV Editora, 2009.

DIAS, V.; FERRI, D.; ALONÇO, A. dos S.; SOUZA, R.S. de. Análise de investimento em plataformas colhedoras de milho em espaçamento reduzido: efeito de oscilações da produtividade, do preço do milho e da semente. Engenharia Agrícola, Jaboticabal, v.29, n.2, p.249-256, 2009.

LAWRENCE, P.R.; LORSCH, J.W. As empresas e o ambiente. Petrópolis: Ed. Vozes, 1973.

ROMANO, L.N. Modelo de referência para o processo de desenvolvimento de máquinas agrícolas. 2003. Tese (Doutorado em Engenharia de Produção) - Universidade de Santa Catarina, Programa de Pós-Graduação em Engenharia Mecânica, Florianópolis, 2003.

ROZENFELD, H.; FORCELLINI, F.A.; AMARAL, D.C. Gestão de desenvolvimento de produtos. Uma referência para a melhoria do processo. São Paulo: Ed. Saraiva, 2006.

TEIXEIRA, S.S.; MACHADO, A.L.T.; REIS, A.V. dos; OLDONI, A. Caracterização da produção agroecológica do sul do Rio Grande do Sul e sua relação com a mecanização agrícola. Engenharia Agrícola, Jaboticabal, v.29, n.1, p.162-171, 2009. 
THOMPSON, J.D. Organizations in action: social science bases of administrative theory transaction publishers. New Brunswick, 1967.

VERNADAT, F.B. Enterprise modeling and integration: principles and applications. London: Chapman \& Hall, 1996. 